\title{
Migration of Oil Bodies in Embryo Cells during Acquisition of Desiccation Tolerance in Chemically Defoliated Corn (Zea mays L.) Seed Production Fields
}

\author{
Ashley N. Dean ${ }^{1,2}$, Katharina Wigg 1,3, Everton V. Zambiazzi 1,4,5, Erik J. Christian ${ }^{1}$, Susana A. Goggi 1,4,*(D), \\ Aaron Schwarte ${ }^{6}$, Jeremy Johnson ${ }^{6}$ and Edgar Cabrera ${ }^{6}$ \\ 1 Department of Agronomy, Iowa State University, Ames, IA 50011, USA; adean@iastate.edu (A.N.D.); \\ wigg@wisc.edu (K.W.); everton_zambiazzi@hotmail.com (E.V.Z.); chrstn@gmail.com (E.J.C.) \\ 2 Department of Entomology, Iowa State University, Ames, IA 50011, USA \\ 3 Department of Horticulture, University of Wisconsin-Madison, Madison, WI 53706, USA \\ 4 Seed Science Center, Iowa State University, Ames, IA 50011, USA \\ 5 Department de Agriculture, Federal University of Lavras, Lavras, Minas Gerais 73200-000, Brazil \\ 6 Corteva Agriscience, Johnston, IA 50131, USA; aaron.schwarte@corteva.com (A.S.); \\ jeremy.johnson@corteva.com (J.J.); cabreraedgarr80@gmail.com (E.C.) \\ * Correspondence: susana@iastate.edu
}

Citation: Dean, A.N.; Wigg, K.; Zambiazzi, E.V.; Christian, E.J.; Goggi, S.A.; Schwarte, A.; Johnson, J.; Cabrera, E. Migration of Oil Bodies in Embryo Cells during Acquisition of Desiccation Tolerance in Chemically Defoliated Corn (Zea mays L.) Seed Production Fields. Agriculture 2021, 11, 129. https://doi.org/10.3390/ agriculture11020129

Academic Editors: Alan G. Taylor and Les Copeland

Received: 11 January 2021

Accepted: 26 January 2021

Published: 5 February 2021

Publisher's Note: MDPI stays neutral with regard to jurisdictional claims in published maps and institutional affiliations.

Copyright: (c) 2021 by the authors. Licensee MDPI, Basel, Switzerland. This article is an open access article distributed under the terms and conditions of the Creative Commons Attribution (CC BY) license (https:/ / creativecommons.org/licenses/by/ $4.0 /)$.

\begin{abstract}
Chemical defoliation of seed corn production fields accelerates seed maturation and desiccation and expedites seed harvest. Early seed harvest is important to minimize the risk of frost damage while in the field. This newly adopted seed production practice also allows seed companies to plan harvest and manage dryer space more efficiently. However, premature defoliation may interfere with the migration of oil bodies within embryo cells during desiccation and affect seed germination and vigor. The objective of this study was to investigate the effect of chemical defoliation on the migration patterns of oil bodies within embryo cells during desiccation. Chemically defoliated and non-defoliated plants from five commercial hybrid seed corn fields were sampled in 2014 and 2015. Whole ears with husks were harvested before and after defoliant application at $600 \mathrm{~g} \mathrm{H}_{2} \mathrm{O} \mathrm{kg}^{-1}$ fresh weight (fw), and weekly thereafter until seed reached approximately $300-350 \mathrm{~g} \mathrm{H}_{2} \mathrm{O} \mathrm{kg}^{-1} \mathrm{fw}$. Ten embryos extracted from center-row seeds were fixed to stop metabolic processes, then sliced, processed, and photographed using scanning transmission electron microscopy. The oil bodies within embryo cells followed normal migration patterns according to seed moisture content, regardless of defoliation treatment. Seed germination and vigor were verified and were not significantly affected by defoliation. Chemical defoliation is a viable production practice to accelerate seed corn desiccation and to manage harvest and seed dryer availability more efficiently without negatively affecting seed germination and vigor.
\end{abstract}

Keywords: corn; seed acquisition of desiccation tolerance; oil-bodies migration; physiological maturity; seed quality

\section{Introduction}

Seed corn (Zea mays L.) is harvested close to physiological maturity and dried artificially in specialized seed dryers before storage. Physiological maturity is the developmental stage at which seeds reach maximum dry weight [1,2]. At this developmental stage, seed moisture content ranges from 300 to $380 \mathrm{~g} \mathrm{H}_{2} \mathrm{O} \mathrm{kg}^{-1}$ fresh weight (fw) depending on the genetic background of the plant and environmental conditions during seed development and maturation [3]. Seed corn is harvested early to avoid possible seed freezing injury caused by an early frost event [4]. The seed industry in the US Upper Midwest experiences significant monetary losses from early frost events every five to six years [5].

Many seed companies have adopted a new seed production practice of chemical defoliation to accelerate seed corn harvest. The defoliant is applied to the plants when 
seed corn is close to $600 \mathrm{~g} \mathrm{H}_{2} \mathrm{O} \mathrm{kg}^{-1} \mathrm{fw}$ or approximately 14 days before normal seed corn harvest. The seed moisture content of chemically defoliated plants decreases more rapidly than in untreated plants because of earlier senescence (personal observation). Chemical defoliation expedites harvest by two to five days, thus widening the harvest window of optimal seed moisture in different hybrid fields. This practice also facilitates harvest schedules and management of seed dryer space.

Although defoliants have been used in cotton to accelerate plant senescence and facilitate mechanical harvest in the US since 1945 [6-8], little is known about the use of defoliants in seed corn production. Drexel Defol ${ }^{\circledR} 5$, a chemical defoliant salt solution used in the US, has not been readily adopted or widespread used. Moreover, the effect of this defoliation treatment on seed quality (seed germination and vigor) has not been fully investigated.

Orthodox seeds, such as corn, undergo a desiccation phase towards the end of seed development. These seeds survive desiccation through physiological changes called acquisition of desiccation tolerance [9]. Seed dehydration is an adaptive mechanism that allows seeds to survive unfavorable weather conditions common in temperate zones. These physiological changes are essential to the normal development of high seed quality. Seed quality in this work is defined as seed germination and vigor.

One important physiological change during the acquisition of desiccation tolerance is the migration and alignment of oil bodies along the cell membrane in corn embryo cells. These oil bodies are accumulated in the cytoplasm of the embryo cell during seed development and, as seeds dehydrate, they migrate to the cell membrane to protect cells from dehydration [10,11]. This migration of oil bodies and alignment alongside of the cell membrane is essential to seed quality.

The objective of this study was to document the migration of oil bodies in embryo cells from chemically defoliated and untreated plants.

\section{Materials and Methods}

\subsection{Seed Production and Defoliation Treatment}

A commercial hybrid seed field was sampled in 2015 near Nevada, Iowa. The field was planted in blocks with a 4:2 female-to-male ratio and managed by the seed company Corteva (Johnston, IA, USA) according to their established hybrid seed production practices.

The chemical defoliant Drexel Defol ${ }^{\circledR} 5\left(42.3\right.$ ai $\mathrm{NaClO}_{3}$ ) (Drexel Chemical Company, Memphis, TN, USA) was applied to the corn plants when seed moisture content was approximately $600 \mathrm{~g} \mathrm{H}_{2} \mathrm{O} \mathrm{kg}^{-1} \mathrm{fw}$ with a Hagie high-clearance sprayer (Hagie Manufacturing Co., Clarion, IA, USA) equipped with a $27.4 \mathrm{~m}$ boom and $68 \mathrm{~L}$ water tank. A strip that was two to three female blocks wide and $800 \mathrm{~m}$ long was not sprayed as a control. Two replications of twenty ears were hand-harvested from the treated and control areas, once prior to the application of the defoliant and at least once a week after application. Sampling continued until the field was mechanically harvested by the seed company when seed moisture content reached approximately $350-370 \mathrm{~g} \mathrm{H}_{2} \mathrm{O} \mathrm{kg}^{-1} \mathrm{fw}$. Therefore, harvest dates are 31 August 2015; 4 September 2015; 11 September 2015; 18 September 2015; and 22 September 2015. Field replications were maintained separately throughout the experiment.

\subsection{Seed Moisture Determination and Seed Drying}

At each sampling date, the sampled ears were brought immediately into the Iowa State University Seed Science Center for processing. All ears were husked by hand within 1 $\mathrm{h}$ after sampling the field. To consistently evaluate seeds at the same developmental stage within the ear [12], seed moisture content was determined on forty seeds removed from the center portion of five ears. Seed were divided into two $5 \mathrm{~cm}$ diameter aluminum trays and placed inside of an $80^{\circ} \mathrm{C}$ oven and weighed daily until seed reached constant weight. 
Moisture content was calculated on a fresh weight basis by using the following formula: (fresh weight - dry weight) fresh weight ${ }^{-1}$.

\subsection{Ultrastructure Determinations}

Ten embryos extracted from seed in the central portion of the ear were prepared for microscopy following the protocol described in Perdomo and Burris [10] with the following modifications. The extracted embryos were dissected in two through the point of attachment perpendicular to the embryo axis to allow the fixative solution to penetrate rapidly throughout the embryo axis. Embryo halves were immediately placed in freshly prepared fixative solution (3\% glutaraldehyde $(w / v)$ and $2 \%$ paraformaldehyde $(w / v)$ in $0.1 \mathrm{M}$ cacodylate buffer, $\mathrm{pH}$ 7.2). Embryos in fixative solution were stored in a refrigerator at $4{ }^{\circ} \mathrm{C}$ for $12-24$ months before they were processed for microscopy. Once fixed, all metabolic processes within the embryo ceases.

For microscopy, samples were dissected and fixed with $3 \%$ glutaraldehyde $(w / v)$ and $2 \%$ paraformaldehyde $(w / v)$ in $0.1 \mathrm{M}$ cacodylate buffer, $\mathrm{pH} 7.2$ for $48 \mathrm{~h}$ at $4{ }^{\circ} \mathrm{C}$. Fixed samples were rinsed three times in $0.1 \mathrm{M}$ cacodylate buffer and then post-fixed in $1 \%$ osmium tetroxide in $0.1 \mathrm{M}$ cacodylate buffer for $1 \mathrm{~h}$ at room temperature. The samples were rinsed in deionized distilled water and enbloc stained with $2 \%$ aqueous uranyl acetate for $1 \mathrm{~h}$, dehydrated in a graded ethanol series, cleared with ultra-pure acetone, infiltrated and embedded using Spurr's recipe epoxy resin (Electron Microscopy Sciences, Ft. Washington, PA, USA). Resin blocks were polymerized for $48 \mathrm{~h}$ at $65^{\circ} \mathrm{C}$. Thick and ultrathin sections were made using a Leica UC6 ultramicrotome (North Central Instruments, Minneapolis, MN, USA). Thick sections were stained with $1 \%$ toluidine blue stain and imaged with an Olympus BX-40 light microscope (Olympus Scientific Solutions Technologies, Waltham, MA, USA). Ultrathin sections were collected onto copper grids and images were captured using a JEOL 2100 scanning and transmission electron microscope (Japan Electron Optic Laboratories, Peabody, MA, USA). Images were captured using an UltraScan 1000 camera (Gatan, Inc., Pleasanton, CA, USA).

\subsection{Seed Quality Determination}

Standard germination tests were conducted on seed from the last harvest according to the Association of Official Seed Analysts (AOSA) rules for testing seeds [13]. One hundred seeds per each treatment and field replication were planted on crepe cellulose paper media (Kimberly Clark Corp., Neenah, WI, USA) moistened with $800 \mathrm{~mL}$ of tap water on fiberglass trays $(45 \mathrm{~cm} \times 66 \mathrm{~cm} \times 2.54 \mathrm{~cm})$. Seeds were lightly pressed into the media to create good seed-media contact. After planting, the trays were placed inside germination carts, and the carts were placed inside a walk-in germination chamber at constant $25^{\circ} \mathrm{C}$ with alternating $8 \mathrm{~h}$ of light and $16 \mathrm{~h}$ of darkness $\mathrm{d}^{-1}$. Final seedling evaluation was performed at 7 days after planting.

Seed vigor was evaluated using the tray-method cold test [14]. One hundred seeds from each treatment and field replication were planted on top of crepe cellulose paper media watered with $1100 \mathrm{~mL}$ of water pre-chilled for $24 \mathrm{~h}$ at $10{ }^{\circ} \mathrm{C}$ on fiberglass trays $(45 \mathrm{~cm} \times 66 \mathrm{~cm} \times 2.54 \mathrm{~cm})$. After planting, trays were covered with approximately $1 \mathrm{~cm}$ of dry $80 \%$ sand: $20 \%$ soil mixture. The trays were placed inside enclosed germination carts, and the carts were placed inside a dark walk-in chamber at constant $10^{\circ} \mathrm{C}$ for 7 days and then moved to a constant $25^{\circ} \mathrm{C}$ walk-in germination chamber with alternating $8 \mathrm{~h}$ of light and $16 \mathrm{~h}$ of darkness $\mathrm{d}^{-1}$. Normal seedlings [13] were evaluated and recorded at 7 days after placing in the constant $25^{\circ} \mathrm{C}$ walk-in germination chamber.

\subsection{Statistical Analysis for Seed Quality}

The two field replications were maintained throughout the experiment, and data were analyzed as a completely randomized design (CRD). The main effects were harvest time and defoliation treatment. All main effects were fixed, and replications were random. 
Data were analyzed using the MIXED procedure of SAS (SAS Institute Inc., Carey, NC, USA) [15]. The analysis of variance was estimated using the restricted maximum likelihood method after testing the data for normality and homozygous error variances. Mean comparisons were made using Fisher's protected least significant difference (LSD) test $(p<0.05)$.

\section{Results}

Light micrographs show the different radicle tissues (Figure 1). Transmission electron microscopy (TEM) micrographs were recorded from the epidermis and cortex cells of the radicle (Figure 1 ).

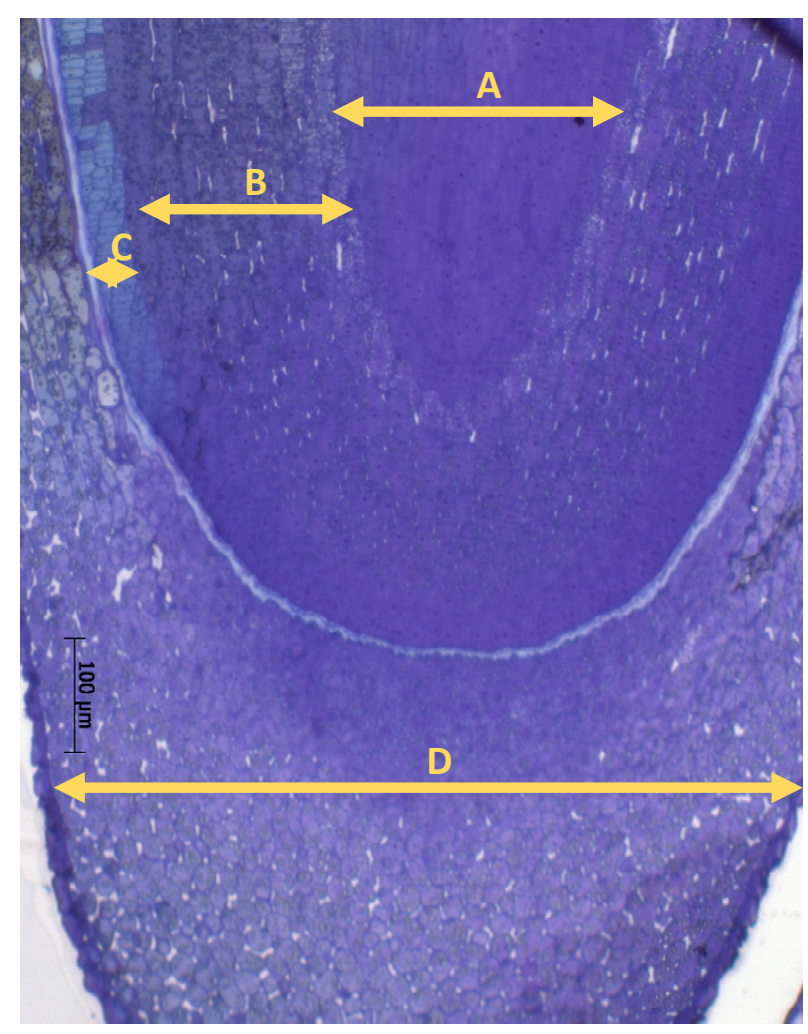

Figure 1. Light microscopy image showing the different tissues of the radicle tip: (A) pericycle; (B) cortex; (C) epidermis; (D) root cap. Magnification $=10 \times$.

Prior to defoliation, the oil bodies in epidermis and cortex cells were located randomly throughout the cytoplasm of the cells (Figure 2). The moisture content of the seed was approximately $600 \mathrm{~g} \mathrm{H}_{2} \mathrm{O} \mathrm{kg}^{-1} \mathrm{fw}$. Four days after defoliant application, seed moisture content decreased to 517 and $509 \mathrm{~g} \mathrm{H}_{2} \mathrm{O} \mathrm{kg}^{-1} \mathrm{fw}$ in the untreated and treated samples, respectively. The oil bodies in epidermis cells showed the initiation of migration and alignment alongside the cell membrane for both treatments, defoliated and non-defoliated plants (Figure 2). However, the oil bodies in cells from the cortex did not show oil bodies migration for the same seed moisture content.

At 11 days after defoliant application, seed moisture content decreased to 434 and $400 \mathrm{~g} \mathrm{H}_{2} \mathrm{O} \mathrm{kg}^{-1} \mathrm{fw}$ in seed samples from the untreated and treated plants, respectively. The migration and alignment of oil bodies along the cell membrane was evident in both tissues, epidermis, and cortex cells. These oil bodies remained aligned along the cell membrane, as observed 18 days after defoliant application (Figure 2). The seed moisture content at this stage was 375 and $368 \mathrm{~g} \mathrm{H}_{2} \mathrm{O} \mathrm{kg}^{-1} \mathrm{fw}$ in the untreated and treated seed samples, respectively (Figure 3). The seed field was harvested immediately after these samples were collected. 


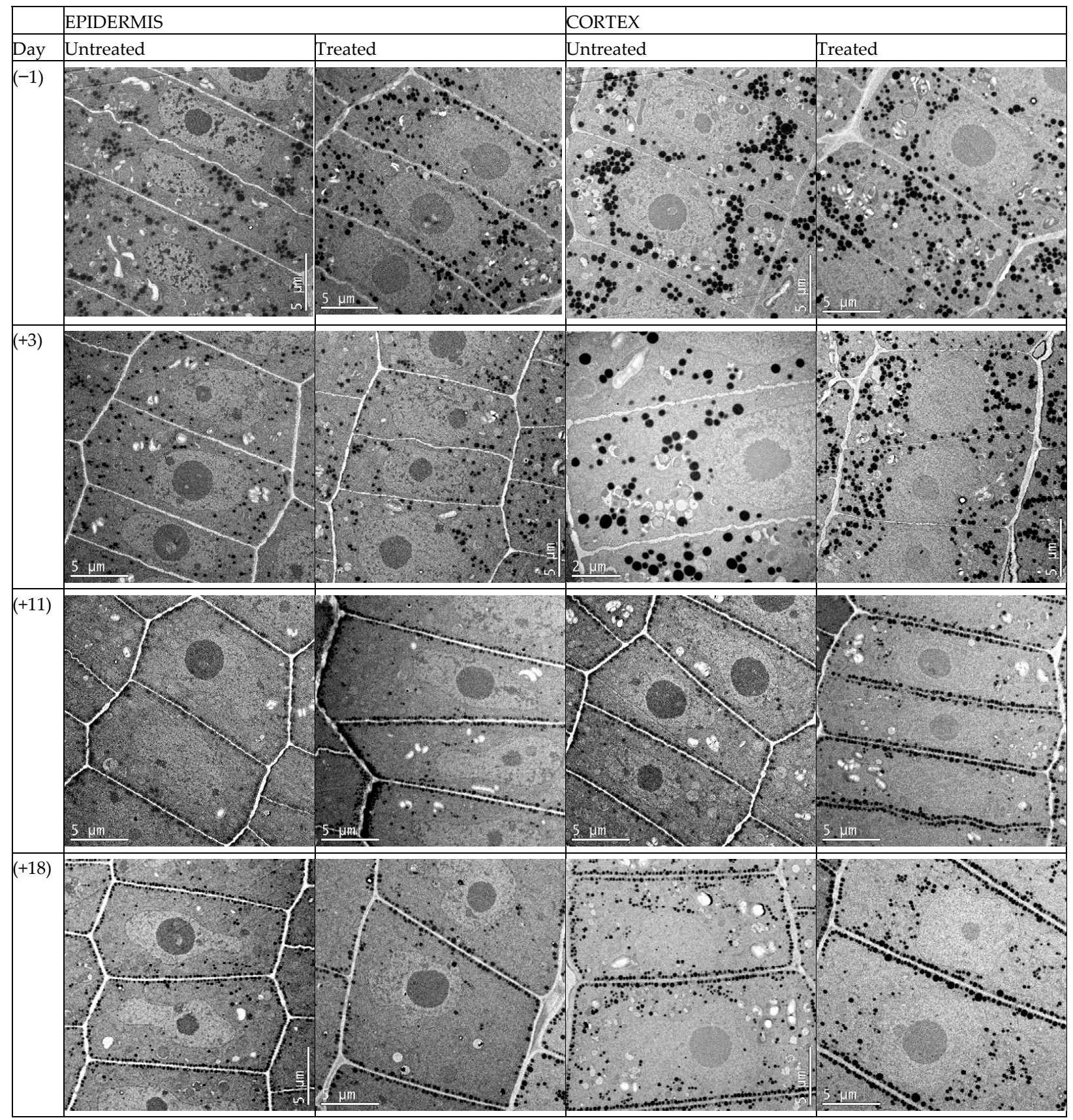

Figure 2. Transmission electron microscopy images of radicle epidermis and cortex cells. Oil body migration is recorded as seed desiccate. All images are taken at $1000 \times$, except for cells in the cortex of untreated plants, which were photographed at $1500 \times$. (Day) Days from defoliant application on the treated plants: day $(-1)$ seeds were harvested and artificially dried with forced ambient air before defoliant application; days $(+3),(+11),(+18)$ indicate seeds were harvested and artificially dried with forced ambient air at 3,11 , and 18 days after defoliant application, respectively. Seed moisture content was expressed on a fresh weight basis as gr $\mathrm{H}_{2} \mathrm{O} \mathrm{kg} \mathrm{seed}{ }^{-1}$ for all treatments. The seed moisture content of untreated plants was 605 on date $(-1) ; 517$ on date $(+3) ; 434$ on date $(+11)$; and 375 on date $(+18)$. The seed moisture content for seed of plants treated with a defoliant were 581 on date $(-1) ; 509$ on date $(+3) ; 430$ on date $(+11)$; and 368 on date $(+18)$. 


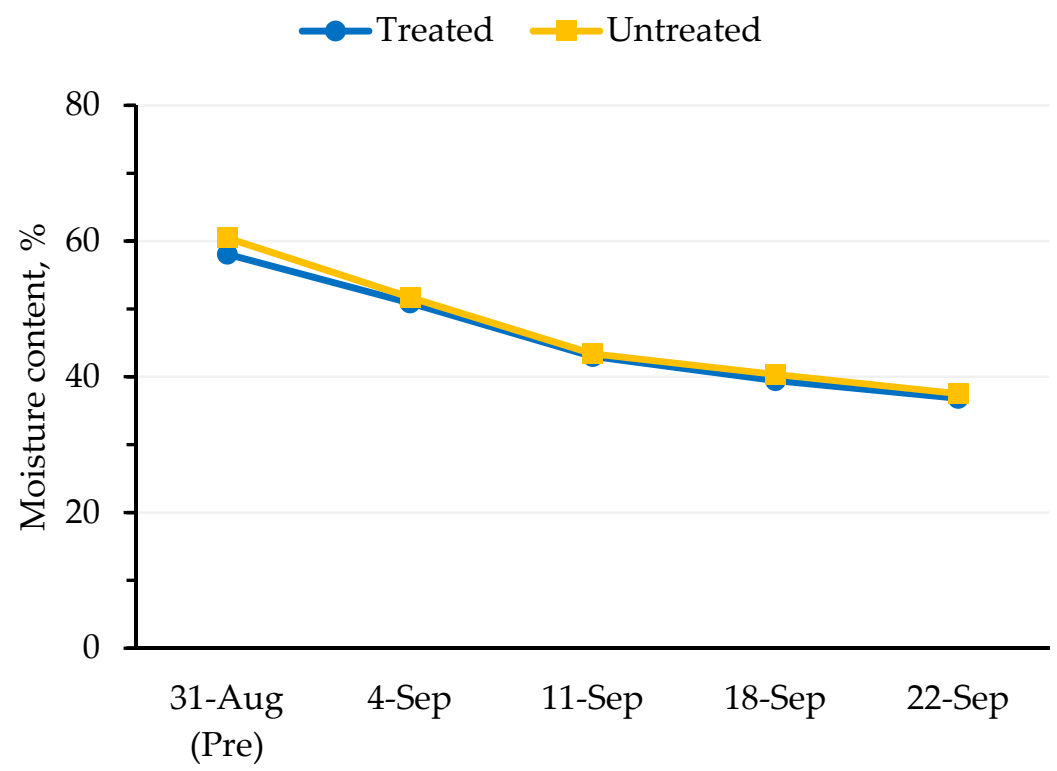

Harvest date

Figure 3. Mean moisture content in percentage at each harvest date for corn hybrid seeds harvested at different harvest dates in 2015. 31-Aug (Pre) refers to harvest before defoliant application; all other harvest dates are post-defoliant application. Aug and Sep indicate the months of August and September. The blue line represents seed moisture values for seed harvested from plants treated with a defoliant; the yellow line represents seed moisture values for seed harvested from the untreated control plants. Means are not significantly different $(p \leq 0.05)$.

The germination (Figure 4) and cold test (Figure 5) values of seed harvested from defoliated and non-defoliated areas were not significantly different $(p \leq 0.05)$.

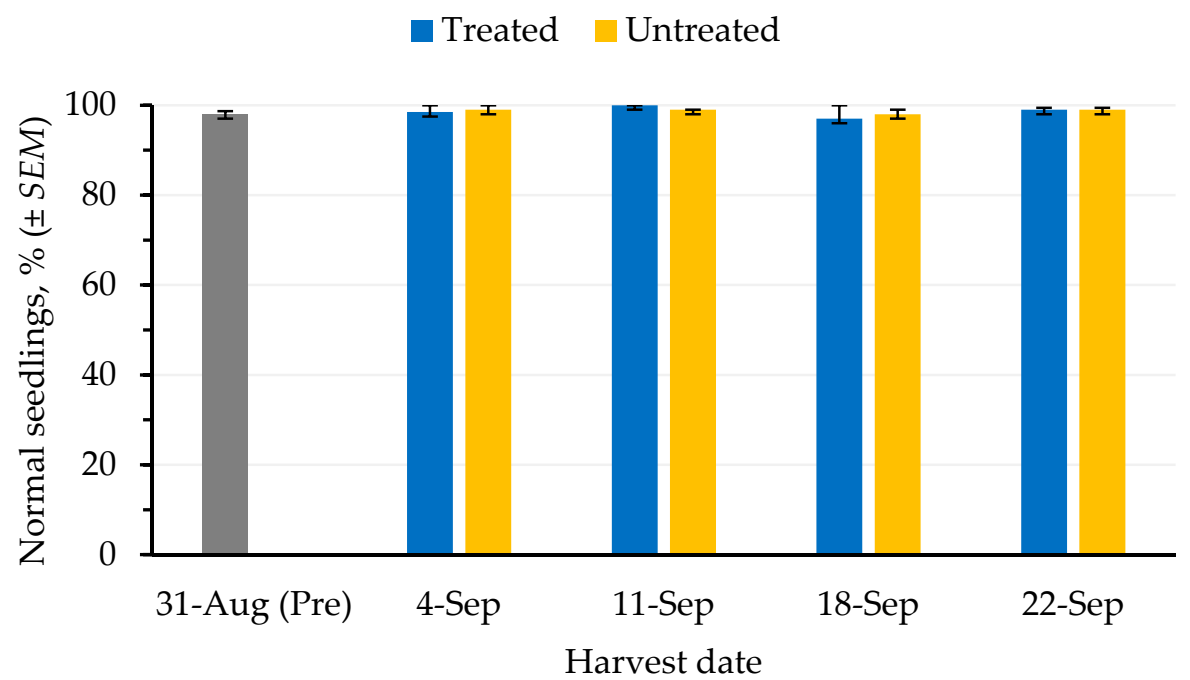

Figure 4. Mean standard germination test values in percentage for corn hybrid seeds harvested at different harvest dates in 2015. 31-Aug (Pre) refers to harvest before defoliant application; all other harvest dates are post-defoliant application. Aug and Sep indicate the months of August and September. Blue columns are the values for seed harvested from plants treated with a defoliant; yellow columns are the values for seed harvested from the untreated control plants. Bars indicate standard error of the mean (SEM). Means are not significantly different $(p \leq 0.05)$. 


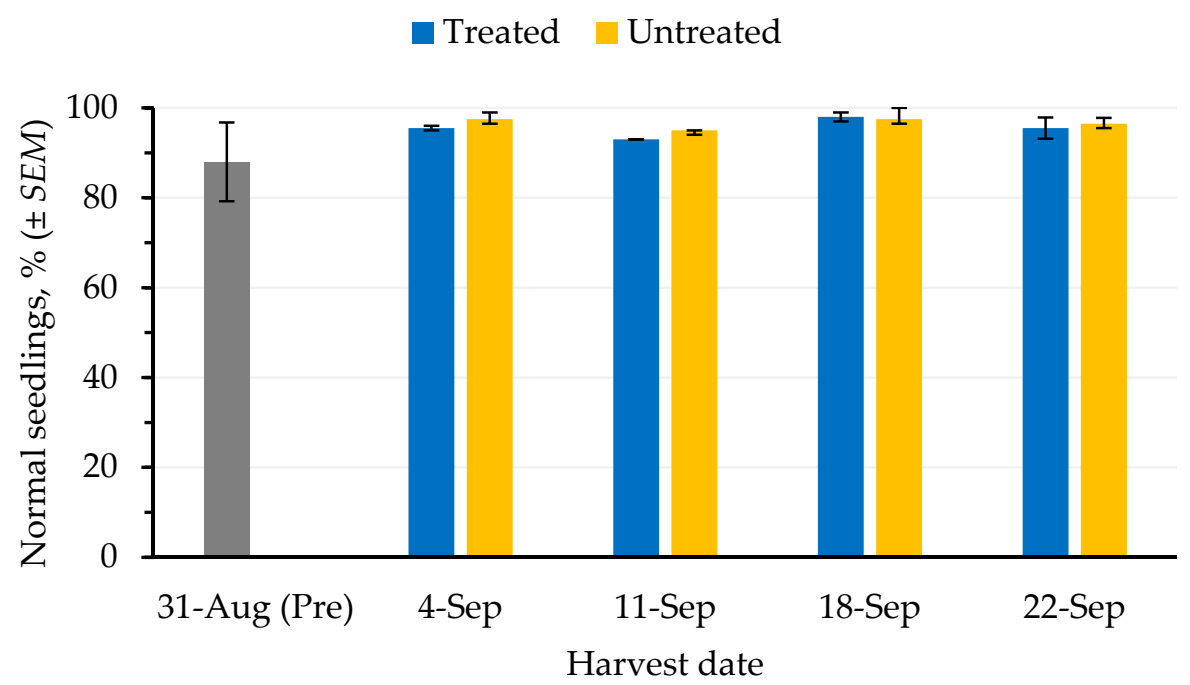

Figure 5. Mean cold test values in percentage for corn hybrid seeds harvested at different harvest dates in 2015. 31-Aug (Pre) refers to harvest before defoliant application; all other harvest dates are post-defoliant application. Aug and Sep indicate the months of August and September. Blue columns are the values for seed harvested from plants treated with a defoliant; yellow columns are the values for seed harvested from the untreated control plants. Bars indicate standard error of the mean (SEM). Means are not significantly different $(p \leq 0.05)$.

\section{Discussion}

The US seed corn market is very competitive [16]. Farmers expect rapid and uniform field emergence of their crop under a wide range of environmental conditions. Cold and wet conditions at planting are common in the upper Midwest of the USA [17]. The use of seeds with high physiological potential is essential to achieve rapid and uniform emergence under these stressful environmental conditions [18]. Seed physiological potential is the maximum at physiological maturity $[1,3]$. Physiological maturity is defined as the developmental stage at which the seed reaches maximum dry weight [1]. Seed physiological potential for this article comprises an active seed metabolic system capable of producing a healthy seedling under a range of environmental conditions in the field (seed germination and vigor). In corn, this developmental stage coincides with black layer formation or the formation of callus tissue that marks the end of seed development and severs the connection between the seed and female parent [3].

The environmental conditions during seed development play a crucial role in seed physiological potential. Abiotic stresses such as plant defoliation during the critical stages of flowering, seed development, and seed maturation can reduce seed yield and seed physiological potential. Freezing temperatures in early fall may cause irreversible damage to cells and reduces seed physiological potential when seed moisture content is greater than $350 \mathrm{~g} \mathrm{H}_{2} \mathrm{O} \mathrm{kg}^{-1} \mathrm{fw}$ [4]. These freezing events cause intercellular and intracellular ice formation within the seed embryo, which results in irreversible damage to cells and reduces seed physiological potential [19]. Consequently, seed corn is harvested on or before physiological maturity and dried artificially. At this developmental stage, seed is also at high moisture content, approximately 300 to $400 \mathrm{~g} \mathrm{H}_{2} \mathrm{O} \mathrm{kg}^{-1} \mathrm{fw}$ [20]. Seed corn is harvested on the cob and artificially dried until seed reaches a safe moisture content for storage, approximately $120 \mathrm{~g} \mathrm{H}_{2} \mathrm{O} \mathrm{kg}^{-1} \mathrm{fw}$ [16]. Seed dryer space may become a limiting factor at the peak of seed corn harvest. In these instances, an early fall frost event can threaten the physiological potential of seed in the field.

Plant defoliation accelerates senescence and seed maturation. Defoliation early in seed development can trigger seed abortion, which lowers seed yields and seed physiological potential. The defoliation stress restricts photosynthesis and reduces the production of sugars necessary for the developing seeds. In sorghum, plants subjected to severe defoliation stress early during seed formation produced larger proportions of low specific gravity 
seeds with extensive hollow areas in the endosperm [21]. In corn, severe defoliation stress approximately 3 weeks after pollination accelerated seed maturation and reduced seed weight [3]. As seed approaches physiological maturity, however, defoliation accelerates seed maturation, with no negative effects on seed physiological potential.

Seed dehydration capacity is unique to orthodox seeds. These seeds are named "orthodox" because they have the capability to dehydrate to very low moisture content of 40 to $50 \mathrm{~g} \mathrm{H}_{2} \mathrm{O} \mathrm{kg}-1 \mathrm{fw}$, while remaining alive. These seeds undergo a series of metabolic changes known as acquisition of desiccation tolerance. The seeds accumulate protective compounds and inactive forms of germination-promoting compounds as they lose water [22]. Also, lipid bodies from the cytoplasm of embryo cells migrate to align along the plasma membranes of the cells [10]. Cells in the root meristem exhibit a distinct migration of the lipid bodies towards the cell walls in response to desiccation. This lipid alignment is essential to seed survival and optimal seed physiological potential [11]. Seeds where lipid alignment is incomplete exhibit an increase in seed leakage during imbibition. The authors theorized that the alignment of lipid bodies along the plasma membrane leads to a more organized dehydration during seed drying [11].

\section{Conclusions}

In our study, plant defoliation late in seed development did not change patterns of lipid-body migration and alignment along the cell membrane. The application of a defoliant resulted in slow plant senescence and seed dehydration. The treated plant senesced a few days earlier, but the difference in moisture content between seeds from the untreated and treated plants remained within 10 to $20 \mathrm{~g} \mathrm{H}_{2} \mathrm{O} \mathrm{kg}{ }^{-1} \mathrm{fw}$. However, the faster seed dehydration time was enough to allow one or two days harvest-date difference between treated and untreated plants. Our study also demonstrated that chemical defoliation did not reduce seed quality, which was defined as germination and vigor in this article. The use of a defoliant allows seed companies to harvest seed earlier, thus reducing the chance of seed deterioration in the field. Farmers also benefit from this technology, as high-quality seed of multiple genetic backgrounds are available for planting.

Even though this defoliation method is not available for use in EU countries, alternative defoliation methods should be investigated to broaden seed harvest timelines and reduce the need for building additional seed dryers when dryer space is limited. These expensive buildings are an additional cost for the seed companies, which may lead to increased production costs and higher seed price.

Author Contributions: Conceptualization: E.J.C., S.A.G., A.S., J.J., and E.C.; Formal analysis: E.V.Z.; Funding acquisition: S.A.G., A.S., J.J., and E.C.; Investigation: A.N.D., K.W., E.J.C., and S.A.G.; Methodology: E.V.Z. and S.A.G.; Project administration: E.J.C., E.V.Z., and S.A.G.; Writing, review and editing: S.A.G., A.N.D., K.W., and E.V.Z. All authors have read and agreed to the published version of the manuscript.

Funding: The APC and Students were funded by Hatch Projects IOW03814, IOW04114, and IOW05594; hybrid corn seed was harvested from Corteva Agriscience Seed Production Fields.

Institutional Review Board Statement: Not applicable.

Informed Consent Statement: Not applicable.

Data Availability Statement: Data available upon request from corresponding author.

Acknowledgments: The authors thank Harry Horner and Tracey P. Stewart at the Roy J. Carver High Resolution Microscopy Facility, Iowa State University, Ames IA, for providing equipment and advice for the microscopy work reported.

Conflicts of Interest: The authors declare no conflict of interest. 


\section{References}

1. Delouche, J.C. Seed maturation. In Proceedings of the Short Course for Seedsmen, Starkville, MS, USA, 5-7 April 1976; Seed Technology Laboratory, Mississippi State University: Mississippi State, MS, USA, 1976; pp. 25-33. Available online: https:/ /ir.library.msstate.edu/handle/11668/13936 (Accessed on 30 November 2020).

2. Hunter, J.L.; Tekrony, D.M.; Miles, D.F.; Egli, D.B. Corn Seed Maturity Indicators and their Relationship to Uptake of Carbon-14 Assimilate. Crop. Sci. 1991, 31, 1309-1313. [CrossRef]

3. Tekrony, D.M.; Hunter, J.L. Effect of Seed Maturation and Genotype on Seed Vigor in Maize. Crop. Sci. 1995, 35, 857-862. [CrossRef]

4. Devries, M.; Goggi, A.S.; Moore, K.J. Determining Seed Performance of Frost-Damaged Maize Seed Lots. Crop. Sci. 2007, 47, 2089-2097. [CrossRef]

5. Burris, J.S.; Knittle, K.H. Freeze damage and seed quality in hybrid maize. Proceedings of Annual Seed Technology Conference, 7th, Ames, IA, USA, 26-27 February 1985; Burris, J.S., Ed.; Seed Science Centre, Iowa State University: Ames, IA, USA, 1985; pp. 51-74.

6. Osborne, D.J. Defoliation and Defoliants. Nat. Cell Biol. 1968, 219, 564-567. [CrossRef] [PubMed]

7. Suttle, J.C. Involvement of Ethylene in the Action of the Cotton Defoliant Thidiazuron. Plant Physiol. 1985, 78, 272-276. [CrossRef] [PubMed]

8. Chu, C.-C.; Henneberry, T.J.; Reynoso, R.Y. Effect of Cotton Defoliants on Leaf Abscission, Immature Bolls, and Lint Yields in a Short-Season Production System. J. Prod. Agric. 1992, 5, 268-272. [CrossRef]

9. Bewley, J.D.; Bradford, K.; Hilhorst, H.; Nonogaki, H. Maturation drying and "switch" to germination. In Seeds: Physiology of Development, Germination and Dormancy, 3rd ed.; Springer: New York, NY, USA, 2013; pp. 57-68.

10. Perdomo, A.; Burris, J.S. Histochemical, Physiological, and Ultrastructural Changes in the Maize Embryo during Artificial Drying. Crop. Sci. 1998, 38, 1236-1244. [CrossRef]

11. Córdova-Téllez, L.; Burris, J.S. Alignment of Lipid Bodies along the Plasma Membrane during the Acquisition of Desiccation Tolerance in Maize Seed. Crop. Sci. 2002, 42, 1982-1988. [CrossRef]

12. Abendroth, L.J.; Elmore, R.W.; Boyer, M.J.; Marlay, S.K. Corn Growth and Development; Iowa State University Extension and Outreach: Ames, IA, USA, 2011.

13. Association of Official Seed Analysts (AOSA). Rules for Testing Seeds; AOSA: Washington, DC, USA, 2015.

14. Association of Official Seed Analysts (AOSA). Seed Vigor Testing Handbook, 3rd ed.; Contribution no. 32; AOSA: Ithaca, NY, USA, 2009.

15. Littell, R.C.; Milliken, G.A.; Stroup, W.W.; Wolfinger, R.D.; Oliver, S. SAS for Mixed Models, 2nd ed.; SAS Institute Inc.: Cary, NC, USA, 2006.

16. Wych, R.D. Production of Hybrid Seed Corn. In Corn and Corn Improvement; Sprague, G.F., Dudley, J.W., Eds.; Agronomy Monographs the American Society of Agronomy, Inc.; Crop Science Society of America, Inc.; Soil Science Society of America, Inc.: Madison, WI, USA, 1988; pp. 565-606. [CrossRef]

17. Kaiser, D.E.; Coulter, J.A.; Vetsch, J.A. Corn Hybrid Response to In-Furrow Starter Fertilizer as Affected by Planting Date. Agron. J. 2016, 108, 2493-2501. [CrossRef]

18. Hegarty, T. The physiology of seed hydration and dehydration, and the relation between water stress and the control of germination: A review. Plant Cell Environ. 1978, 1, 101-119. [CrossRef]

19. Woltz, J.; TeKrony, D.M.; Egli, D.B. Corn seed germination and vigor following freezing during seed development. Crop Sci. 2006, 46, 1526-1535. [CrossRef]

20. Cordova-Tellez, L.; Burris, J.S. Embryo Drying Rates during the Acquisition of Desiccation Tolerance in Maize Seed. Crop. Sci. 2002, 42, 1989-1995. [CrossRef]

21. Goggi, A.S.; Delouche, J.C.; Gourley, L.M. Sorghum [Sorghum bicolor (L.) Moench] seed internal morphology related to seed specific gravity, weathering, and immaturity. J. Seed Technol. 1993, 17, 1-11.

22. Gutierrez, L.; Van Wuytswinkel, O.; Castelain, M.; Bellini, C. Combined networks regulating seed maturation. Trends Plant Sci. 2007, 12, 294-300. [CrossRef] [PubMed] 